\title{
Kajian Pengembangan Sediaan Nanosuspensi Untuk Penghantaran Intravena Obat Sukar Larut Air
}

\author{
Sani Ega Priani* \\ Program Studi Farmasi, Fakultas MIPA, UNISBA, Jawa Barat, Indonesia \\ *E-mail: egapriani@gmail.com \\ (Submit 23/12/2021, Revisi 19/01/2022, Diterima 18/02/2022, Terbit 03/03/2022)
}

\begin{abstract}
Abstrak
Pengembangan bentuk sediaan perlu dilakukan untuk penghantaran intravena senyawa aktif dengan kelarutan yang rendah dalam air. Nanosuspensi sebagai suatu produk nanoteknologi banyak diaplikasikan untuk tujuan tersebut. Penelitian ini bertujuan untuk mengkaji pengembangan sistem nanosuspensi untuk penghantaran intravena obat sukar larut air dalam hal pemilihan jenis penstabil serta pengkajian pengaruhnya terhadap disolusi, pelepasan, profil farmakokinetika, dan keamanan penggunaan. Penelitian dilakukan dengan systematic literature review (SLR), menggunakan artikel ilmiah dari database bereputasi yang memenuhi kriteria inklusi dan eksklusi yang telah ditetapkan dalam review ini. Hasil kajian menunjukkan bahan penstabil utama yang digunakan pada pengembangan nanosuspensi intravena adalah poloxamer, lesitin, TPGS (D-a-tocopheryl polyethylene glycol 1000 succinate), dan BSA (bovine serum albumin) yang bersifat biokompatibel, non toksik, dengan memperhatikan kadar maksimal menurut FDA's Inactive Ingredient Database for IV route. Pengembangan nanosuspensi secara signifikan mampu meningkatkan disolusi dan pelepasan zat aktif dibandingkan dengan bentuk murni/suspensi. Pengembangan nanosuspensi pada beberapa bahan aktif mampu merubah profil farmakokinetika yang ditandai dengan peningkatan nilai AUC (Area Under Curve), Cmax, dan MRT (Mean Residence Time) dengan memberikan profil pelepasan diperlambat (sustained release). Pengembangan nanosuspensi pada beberapa bahan aktif terbukti aman digunakan secara intravena berdasarkan uji hemolisis dan iritasi vaskular. Berdasarkan kajian yang telah dilakukan diketahui bahwa nanosuspensi sesuai dan potensial diaplikasikan sebagai penghantaran intravena obat sukar larut air, berdasarkan kajian terhadap disolusi, pelepasan, profil farmakokinetika, dan keamanan.
\end{abstract}

Kata kunci: nanosuspensi, intravena, obat sukar larut air, disolusi, farmakokinetika 


\section{Pendahuluan}

Nanoteknologi saat ini terus berkembang dan dimanfaatkan untuk berbagai sistem penghantaran obat (1). Kemampuannya untuk meningkatkan kelarutan dan permeabilitas, memfasilitasi sistem penghantaran obat tertarget, menjadi beberapa keuntungan aplikasi nanoteknologi di bidang farmasi (2). Produk dari nanoteknologi tersebut dapat berupa liposom, nanokristal, nanoenkapsulasi, nanoemulsi, nanosuspensi, nanopartikel logam, polimerik misel, dendrimer, dan lain lain (3). Setiap bentuk sediaan berbasis nanoteknologi tersebut, memiliki kekhasan, kelebihan, dan kekurangan masing-masing (4).

Nanosuspensi adalah salah satu bentuk sediaan berbasis nanoteknologi (5). Nanosuspensi merupakan sistem dispersi koloidal mengandung partikel obat dengan ukuran $<1 \mu \mathrm{m}$ yang distabilkan oleh surfaktan dan atau polimer (6). Surfaktan dan polimer bekerja mencegah terjadinya kembali aglomerasi partikel dengan mekanisme stabilisasi sterik, elektrostatik, atau elektrosterik (7). Stabilisasi sterik pada sediaan nanosuspensi terjadi dengan pembentukan hambatan ruang antar partikel oleh molekul penstabil yang teradsorpsi pada permukaan. Stabilisasi elektrostatik terjadi akibat gaya tolak menolak antar partikel yang timbul akibat terbentuknya muatan pada permukaan partikel. Sedangkan stabilisasi elektrosterik adalah stabilisasi akibat kombinasi efek sterik dan elektrostatik (8). Nanosuspensi banyak dikembangkan karena kemampuannya untuk meningkatkan kelarutan dan bioavailabilitas obat (9). Sediaan nanosuspensi sesuai untuk pengembangan obat yang memiliki kelarutan yang rendah dalam air, titik leleh tinggi, dan obat dengan dosis tinggi. Teknologi nanosuspensi juga dapat diaplikasikan untuk bahan aktif yang tidak larut dalah air juga dalam pelarut organik $(7,9)$.

Nanosuspensi dapat dibuat dengan dua metode yakni metode top down dan bottom up (11). Top down adalah pembentukan nanosuspensi dengan pengecilan ukuran partikel dari dispersi kasar menjadi sistem koloidal yang bisa dilakukan dengan teknik wet/dry milling, high pressure homogenization, dan co-grinding (12). Sedangkan buttom up adalah pembentukan sistem nanoemulsi dari dispersi molekular menjadi koloidal, yang dapat dilakukan dengan teknik antisolvent precipitation, liquid emulsion, dan sonoprecipitation (13).

Sistem nanosuspensi dapat diaplikasikan untuk berbagai rute pemberian obat seperti oral, optalmik, topikal, dan parenteral (14). Ukuran partikel pada sistem nanosuspensi membuatnya memungkinkan untuk menghantarkan obat secara parenteral, khususnya dengan rute intravena (15). Rute intravena diketahui memberikan onset obat yang cepat, menghindari efek metabolisme lintas pertama, dan memungkinkan terjadinya penghantaran obat tertarget (site specific delivery) (16). Sistem nanosuspensi dapat membantu menghantarkan obat melalui rute intravena, dengan memperkecil ukuran partikel sehingga mencegah terjadinya penyumbatan aliran darah dan meningkatkan kelarutan (17). Penggunaan obat secara intravena dengan menggunakan bahan penstabil (polimer/surfaktan) dalam formulasi nanosuspensi harus sangat diperhatikan guna menjamin keamanan penggunaan (18). 
Artikel ini mengkaji penerapan sistem nanosuspensi pada penghantaran obat sukar larut air untuk penggunaan intravena. Pengkajian meliputi jenis bahan polimer yang digunakan dan juga pengaruh pengembangan sistem nanosuspensi terhadap disolusi/pelepasan zat aktif, profil farmakokinetika, dan keamanan penggunaan secara intravena.

\section{Metode}

Penelitian disusun berbasis systematic literature review (SLR), dengan beberapa tahapan yang dilakukan yaitu pencarian literatur, seleksi, ekstraksi data, dan pelaporan. Pencarian artikel dilakukan di database: Science Direct (Elsevier), Springer, Taylor and Francis, John Wiley and Sons, dan PubMed. Kata kunci yang dilakukan untuk proses pencarian adalah 'nanosuspension'; 'parenteraf; 'intravenous'. Dipilih artikel yang dipublikasikan pada 10 tahun terakhir (2012-2021) dan diperoleh 502 artikel dan selanjutnya diseleksi merujuk pada kriteria inklusi dan eksklusi. Kriteria inklusi adalah artikel penelitian tentang pengembangan nanosuspensi untuk penghantaran intravena. Sedangkan sebagai kriteria eksklusi adalah artikel berbentuk review, artikel nanosuspensi tanpa evaluasi in vitro/in vivo, artikel nanosuspensi yang tidak berkaitan dengan tujuan kajian. Diperoleh 20 artikel terpilih yang memenuhi kriteria inklusi dan eksklusi dengan rincian 3 dari laman pubmed, 8 dari laman science direct dan 9 dari laman taylor and francis. Dari 20 artikel tersebut diketahui ada 3 duplikasi artikel, sehingga yang akhirnya proses adalah 17 artikel. Dari seluruh artikel selanjutnya dilakukan ekstraksi data yang berkaitan dengan jenis penstabil yang digunakan, profil disolusi, pelepasan, dan farmakokinetika zat aktif, serta kajian keamanan penggunaan secara intravena $(18,19)$.

\section{Hasil}

Nanosuspensi merupakan sistem nanodispersi dari zat aktif sukar larut air yang distabilkan oleh polimer dan atau surfaktan (21). Pada tabel 1, diperlihatkan data beberapa jenis senyawa tidak larut air yang telah dikembangkan menjadi sediaan nanosuspensi disertai dengan keterangan jenis penstabil yang digunakan serta hasil karakteristik fisiknya. Berdasarkan data yang ditampilkan pada tabel 1, terlihat sudah banyak senyawa yang dikembangkan menjadi sediaan nanosuspensi untuk tujuan penghantaran parenteral khususnya intravena. Senyawa-senyawa tersebut yakni 2methoxyestradiol (22), MTKi-327 (multi-targeted kinase inhibitor) (23), azritomisin (24), curcumin (25), bifendat (26), dosetaxel (27), PIK-75 (phosphatidylinositol 3-kinase) $(27,28)$, p-terphenyl derivative (30), sorafenib (31), genkwanin (32), hydroxy genkwanin (33), paclitaxel (34), etopiside (35), dan hydroxycamptothecin (36). Senyawa-senyawa tersebut mayoritas berkhasiat sebagai agen sitotoksik untuk pengobatan kanker, kecuali azritomisin sebagai antibiotik dan bifendat sebagai antivirus. Semua senyawa tersebut memiliki kelarutan yang rendah dalam air, sehingga sulit untuk bisa langsung diberikan secara intravena. Dari hasil kajian diketahui bahwa pengembangan sediaan nanosuspensi terhadap zat-zat tersebut berpengaruh positif baik terhadap kelarutan, pelepasan, profil farmakokinetik, dan keamanan pemberiaan secara intravena. 
Pengembangan nanosuspensi pada senyawa tersebut dilakukan untuk memperkecil ukuran partikelnya dan memperbaiki kelarutan sehingga memfasilitasi penghantaran intravena (21). Seluruh sediaan nanosuspensi memiliki ukuran partikel yang sesuai yakni berada pada rentang 147-261 nm, sehingga memungkinkan untuk diinjeksikan secara intravena. Untuk mencegah partikel-partikel tersebut bergabung kembali ditambahkan bahan penstabil ke dalam sediaan nanosuspensi tersebut. Berdasarkan data yang ditampilkan pada tabel 1, diketahui bahwa bahan penstabil yang banyak dikembangkan untuk sediaan nanosuspensi intravena adalah poloxamer 188, lesitin, TPGS (D-a-tocopheryl polyethylene glycol 1000 succinate), dan albumin.

Pada tabel 2 ditampilkan pengaruh pengembangan sediaan nanosuspensi terhadap disolusi zat aktif. Pengujian disolusi yang dilakukan terhadap azritomisin, hydroxy camptothecin, curcumin, bifendate, dan PIK-75 yang diformulasikan dalam bentuk sediaan nanosuspensi, menunjukkan terjadinya peningkatan yang sangat signifikan pada nilai \% disolusinya. Selain uji disolusi beberapa penelitian juga melakukan uji pelepasan zat aktif (in vitro drug release). Pengujian dilakukan dengan melihat kemampuan zat aktif untuk bisa lepas menembus membran dialisis (tabel 3). Dari hasil kajian diketahui bahwa sediaan nanosuspensi dapat meningkatkan \% pelepasan zat aktif dengan pengujian secara in vitro bila dibandingkan dengan bentuk sediaan suspensinya. Hal ini terjadi pada nanosuspensi genkwanin (32), hydroxy genkwanin (33), dan sorafenib (31) .

Kajian selanjutnya berkaitan dengan pengaruh pengembangan nanosuspensi terhadap profil farmakokinetika zat aktif setelah pemberian secara intravena (tabel 4). Berdasarkan data pada tabel 4, dapat dikatakan secara umum pengembangan sediaan nanosuspensi memberikan pengaruh signifikan terhadap profil farmakokinetika terutama pada nilai area under curve (AUC), Cmax, dan mean residence time (MRT). Pengembangan sediaan nanosuspensi terhadap MTKi-31 (23), hydroxyicamptothecin (36), curcumin (25), bifendat (26), pactitaxel (34), dan p-therpenyl derivate (30), secara umum meningkatkan nilai AUC (area under curve), Cmax, dan MRT (mean residence time).

Beberapa penelitian juga telah melakukan uji untuk menilai keamanan dari penggunaan nanosuspensi secara intravena. Pengujian dilakukan dalam bentuk erythrocyte hemolysis test dan vascular irritability test. Pengujian dilakukan untuk menilai resiko terjadinya hemolisis sel darah dan iritasi vaskular akibat pemberian sediaan secara intravena (37). Dari sejumlah artikel yang dikaji hanya sebagian kecil yang sudah melakukan pengujian ini yakni hanya pada nanosuspensi curcumin, sorafenib, genkwanin, dan hydroxy genkwanin. Dari ke-4 artikel tersebut, terlihat bahwa pemberian nanosuspensi aman digunakan secara intravena ditandai dengan nilai erythrocyte hemolysis rate $<5 \%$ dan tidak terjadinya kerusakan histopatologi vaskular (tabel 5). 
Tabel 1. Formulasi dan hasil karakterisasi nanosuspensi agen sitotoksik

\begin{tabular}{|c|c|c|c|c|}
\hline Nama zat & Penstabil & $\begin{array}{c}\text { Metode } \\
\text { pembuatan }\end{array}$ & $\begin{array}{l}\text { Karakteristik } \\
\text { nanosuspensi }\end{array}$ & $\begin{array}{l}\text { Pusta } \\
\text { ka }\end{array}$ \\
\hline 2-methoxyestradiol & $\begin{array}{l}\text { Poloxamer } 1883 \% \text {, } \\
\text { CMC Na } 0,6 \% \text {, } \\
\text { Na lauril sulfat } 0,1 \%\end{array}$ & $\begin{array}{c}\text { Bottom up } \\
\text { (nanoprecipitatio } \\
n- \\
\text { ultrasonication) }\end{array}$ & $\begin{array}{c}\text { UP: } 168,4 \pm 3,2 \mathrm{~nm} \\
\text { PDI: } 0,25 \pm 0,02, \\
\text { PZ: }-29,7 \pm 1,8 \\
m V\end{array}$ & $(22)$ \\
\hline $\begin{array}{c}\text { MTKi-327 } \\
\text { (multi-targeted } \\
\text { kinase inhibitor- } \\
\text { 327) }\end{array}$ & $\begin{array}{c}\text { Pluronic F108 } \\
\text { 2,5\%, lipoid } \\
\text { s75/lesitin 0,3\% }\end{array}$ & $\begin{array}{c}\text { Top down } \\
\text { (the roller milling } \\
\text { method) }\end{array}$ & $\begin{array}{c}\text { UP }: 195 \pm 5,6 \\
n m \\
\text { PDI : } 0,1 \pm 0,001 \\
P Z: 19,6 \pm \\
2,1 \mathrm{mv}\end{array}$ & (23) \\
\hline $\begin{array}{c}\text { PIK-75 } \\
\text { (Phosphatidylinosit } \\
\text { ol 3-kinases) }\end{array}$ & $\begin{array}{l}\text { Poloxamer } 188 \\
0,4 \% \text { dan Soya- } \\
\text { lesitin } 0,4 \%\end{array}$ & $\begin{array}{c}\text { Top down } \\
\text { (high pressure } \\
\text { homogenixation) }\end{array}$ & $\begin{array}{c}\text { UP: } 182 \pm 45 \mathrm{~nm} \\
\text { PDI : } 0,2 \pm 0,1 \\
\text { ZP: }-39 \pm 0,9 \\
m V\end{array}$ & $\begin{array}{c}(28,29 \\
)\end{array}$ \\
\hline $\begin{array}{l}\text { p-terphenyl } \\
\text { derivative }\end{array}$ & $\begin{array}{c}\text { Poloxamer } 188 \\
0,08 \% \text { dan Soya- } \\
\text { lesitin } 0,8 \%\end{array}$ & $\begin{array}{c}\text { Bottom up } \\
\text { (precipitation- } \\
\text { microfluidizer) }\end{array}$ & $\begin{array}{c}\text { UP: } 201,7 \pm 5,8 \\
n m \\
\text { PDI:0,17 } \pm 0,018 \\
\text { ZP:-21, } 1 \pm 0,5 \\
m V\end{array}$ & (30) \\
\hline Azritomisin & Lesitin $1 \%$ & $\begin{array}{c}\text { Bottom up } \\
\text { (reactive } \\
\text { precipitation) }\end{array}$ & $\begin{array}{c}\text { UP : } 200 \pm 20 \mathrm{~nm} \\
\mathrm{PZ}:-36,7 \pm 7,6 \\
\mathrm{mV}\end{array}$ & (24) \\
\hline \multirow[t]{2}{*}{ Curcumin } & $\begin{array}{l}\text { lesitin } 0,2 \% \text { \& } \\
\text { sodium } \\
\text { deoxycholate } 0,2 \%\end{array}$ & $\begin{array}{c}\text { Top down } \\
\text { (high pressure } \\
\text { homogenixation) }\end{array}$ & $\begin{array}{c}\text { UP : } \\
176,31 \pm 2,55 \\
\text { ZP : }-27,92 \mathrm{mV}\end{array}$ & (25) \\
\hline & TPGS 1\% & $\begin{array}{c}\text { Top down } \\
\text { (high pressure } \\
\text { homogenixation) }\end{array}$ & $\begin{array}{l}\text { UP : } 210.2 \mathrm{~nm} \\
\text { PDI: } 0.123 \\
\text { ZP : }-14.8 \\
\pm 1.7 \mathrm{mV}\end{array}$ & $(51)$ \\
\hline Bifendat & $\begin{array}{l}\text { Lesitin } 0,2 \% \text { dan } \\
\text { PVPK30 0,05\% }\end{array}$ & $\begin{array}{c}\text { Bottom up } \\
\text { (precipitation- } \\
\text { microfluidizer) }\end{array}$ & $\begin{array}{c}\text { UP : } 208 \pm 9,53 \\
n m \\
\text { PDI : } 0,357 \\
\pm 0,05 \\
\text { ZP : } 21,1 \pm 0,6 \\
m V\end{array}$ & $(26)$ \\
\hline
\end{tabular}




\begin{tabular}{|c|c|c|c|c|}
\hline Docetaxel & Lesitin & $\begin{array}{c}\text { Top down } \\
\text { (high pressure } \\
\text { homogenixatio } \\
\text { n) }\end{array}$ & $\begin{array}{c}\text { UP: } 204,2 \pm \\
6,2 \mathrm{~nm} \\
\text { PDI: } 0,192 \pm \\
0,010 \\
\text { ZP :-33,8 } \pm \\
0,3 \mathrm{mV}\end{array}$ & $\overline{(27)}$ \\
\hline Sorafenib & $\begin{array}{l}\text { Lesitin } 0,75 \% \text { dan } \\
\text { Tween } 80 \quad 1,5 \%\end{array}$ & $\begin{array}{c}\text { Bottom up } \\
\text { (nanopresipitas } \\
\text { i) }\end{array}$ & $\begin{array}{c}\text { UP : } 164,5 \pm 4,5 \\
\text { nm } \\
\text { PDI: } \\
0,202 \pm 0,015 \\
\text { ZP:- } 11 \pm 0,28 \\
\text { mV }\end{array}$ & (31) \\
\hline Genkwanin & TPGS & $\begin{array}{c}\text { Bottom up } \\
\text { (antisolvent } \\
\text { precipitation) }\end{array}$ & $\begin{array}{c}\text { UP: } 183,1 \pm 4,4 \\
n m \\
\text { PDI: } 0,16 \pm 0,07 \\
\text { ZP: }-16,2 \pm 0,1 \\
m V\end{array}$ & (32) \\
\hline Paclitaxel & TPGS 0,4\% & $\begin{array}{c}\text { Bottom up } \\
\text { (antisolvent } \\
\text { precipitation) }\end{array}$ & $\begin{array}{l}\text { UP :147,3 } \pm \\
6,3 \mathrm{~nm}\end{array}$ & (34) \\
\hline $\begin{array}{l}\text { Hydroxy } \\
\text { genkwanin }\end{array}$ & TPGS & Bottom up & $\begin{array}{l}\text { UP : } 261,1 \pm \\
4,8 \mathrm{~nm} \\
\text { PDI : } 0,12 \pm \\
0,01 \\
\text { ZP : }-27,5 \pm 1,5 \\
m V\end{array}$ & (33) \\
\hline Etoposide & $\begin{array}{l}\text { Bovine serum } \\
\text { albumin/BSA 3\% }\end{array}$ & $\begin{array}{c}\text { Bottom up } \\
\text { (antisolvent } \\
\text { precipitation- } \\
\text { HPH) }\end{array}$ & $\begin{array}{c}\text { UP: } 190,2 \pm 7,3 \\
n m \\
\text { PDI: } 0,29 \pm 0,08 \\
\text { ZP: } 23,05 \pm \\
1,78 \mathrm{mv}\end{array}$ & (35) \\
\hline $\begin{array}{c}\text { Hydroxycamptoth } \\
\text { ecin }\end{array}$ & Fetal calf serum & $\begin{array}{c}\text { Bottom up } \\
\text { (precipitation- } \\
\text { ultrasonication) }\end{array}$ & $\begin{array}{c}\text { UP: } 168,2 \pm \\
2,85 \mathrm{~nm} \\
\text { PDI } 0.168 \pm \\
0.023\end{array}$ & (36) \\
\hline
\end{tabular}

Keterangan : UP (ukuran partikel), PDI (poli dispersity index), ZP (zeta potensial) 
Tabel 2. Pengaruh sistem nanosuspensi terhadap disolusi

\begin{tabular}{|c|c|c|}
\hline Nama zat & \% Disolusi & Pustaka \\
\hline Azritomisin & $\begin{array}{l}\text { Physical mixture: } \\
\text { Nanosuspensi : } 90 \%\end{array}$ & $80 \% \quad(24)$ \\
\hline Hydroxycamptothecin & $\begin{array}{l}\text { Suspensi : } 37,5 \% \\
\text { Nanosuspensi : } 96,22 \%\end{array}$ & (36) \\
\hline Curcumin & $\begin{array}{l}\text { Zat murni : } 12 \% \\
\text { Nanosuspeni: } 86,9 \%\end{array}$ & (51) \\
\hline & $\begin{array}{l}\text { Zat murni: } 19,9 \% \\
\text { Nanosuspensi: } 100 \%\end{array}$ & (25) \\
\hline Bifendate & $\begin{array}{l}\text { Zat murni : } 50,4 \% \\
\text { Nanosuspensi } 100 \%\end{array}$ & (26) \\
\hline PIK 75 & $\begin{array}{l}\text { Zat murni }=38 \% \\
\text { Nanosuspensi }=89 \%\end{array}$ & (29) \\
\hline
\end{tabular}

Tabel 3. Pengaruh nanosuspensi terhadap pelepasan zat aktif

\begin{tabular}{ccr}
\hline Nama zat & Pengaruh pada pelepasan & Pustaka \\
\hline Hydroxycamptothecin
\end{tabular}

Hydroxycamptothecin Injeksi HCPT (marketed) : 84\% selama 0,5 (36) (HCPT) jam

Nanosuspensi HCPT: $84.9 \%$ selama 5 jam

Genkwanin Suspensi genkwanin : $22.0 \%$

Nanosuspensi genkwanin : 70, 2\%

Hidroxy genkwanin Suspensi hidroxy genkwanin : 0\%

Nanosuspensi genkwanin : $83.9 \%$ dengan sistem sustained release

\begin{tabular}{ll}
\hline Etoposide & Injeksi etoposide (marketed) : $100 \%$ \\
& Nanosuspensi etoposide : $100 \%$ dengan \\
& sistem lepas lambat (sustained release)
\end{tabular}

Sorafenib

Suspensi sorafenib : $34.53 \%$

Nanosuspensi sorafenib : $45.75 \%$ 
Tabel 4. Pengaruh nanosuspensi terhadap profil farmakokinetikari

\begin{tabular}{|c|c|c|}
\hline Nama zat & Pengaruh pada farmakokinetika & Pustaka \\
\hline \multirow[t]{4}{*}{ MTKi-327 } & AUC larutan : $760 \pm 190 \mathrm{ng} \mathrm{h/ml}$ & (23) \\
\hline & AUC nanosuspensi : $1785 \pm 323 \mathrm{ng} \mathrm{h} / \mathrm{ml}$ & \\
\hline & Cmax larutan : $940 \pm 393 \mathrm{ng} / \mathrm{mL}$ & \\
\hline & Cmax nanosuspensi : $5076 \pm 1709 \mathrm{ng} / \mathrm{mL}$ & \\
\hline \multirow{2}{*}{$\begin{array}{l}\text { Hydroxycamptotheci } \\
n \text { (HCPT) }\end{array}$} & AUC larutan: $0,096 \pm 0,044 \mu \mathrm{g} . \mathrm{h} / \mathrm{g}$ & (36) \\
\hline & AUC nanosuspensi : $0,840 \pm 0,406 \mu \mathrm{g} \cdot \mathrm{h} / \mathrm{g}$ & \\
\hline \multirow[t]{6}{*}{ Curcumin } & AUC larutan : $145,42 \pm 9,29 \mu \mathrm{g} / \mathrm{mL} \min$ & $(51)$ \\
\hline & AUC nanosuspensi : $700,43 \pm 281,53 \mu \mathrm{g} / \mathrm{mLmin}$ & \\
\hline & Cmax larutan : $8,17 \pm 0,93 \mu \mathrm{g} / \mathrm{mL}$ & \\
\hline & Cmax nanosuspensi : $25,54 \pm 6,2 \mu \mathrm{g} / \mathrm{mL}$ & \\
\hline & MRT larutan: $15,88 \pm 3,56$ minutes & \\
\hline & MRT nanosuspensi: $194.57 \pm 32.18$ menit & \\
\hline \multirow[t]{6}{*}{ Bifendat } & AUC larutan : $3,741 \pm 0,35 \mathrm{mg} \cdot \mathrm{h} / \mathrm{mL}$ & $(26)$ \\
\hline & AUC nanosuspensi : $64,281 \pm 2,47 \mathrm{mg} \cdot \mathrm{h} / \mathrm{mL}$ & \\
\hline & Cmax larutan : 2,09 $\pm 0,21 \mathrm{mg} / \mathrm{mL}$ & \\
\hline & Cmax nanosuspensi : $22,3 \pm 1,01 \mathrm{mg} / \mathrm{mL}$ & \\
\hline & MRT larutan :1,516 $\pm 0,12 \mathrm{jam}$ & \\
\hline & MRT nanosuspensi : 2,772 $\pm 0,05$ jam & \\
\hline \multirow[t]{4}{*}{ Paclitaxel } & AUC larutan : $11,40 \pm 3,5 \mathrm{mg} / \mathrm{L} \mathrm{h}$ & (34) \\
\hline & AUC nanosuspensi : $13,15 \pm 4,1 \mathrm{mg} / \mathrm{L} \mathrm{h}$ & \\
\hline & MRT Iarutan : 6,02 $\pm 1,7$ jam & \\
\hline & MRT nanosuspensi : $14,79 \pm 1,9$ jam & \\
\hline \multirow[t]{4}{*}{ PIK-75 } & Cmax suspensi : $3,7 \pm 0,4 \mu \mathrm{g} \cdot \mathrm{h} / \mathrm{mL}$ & $(28)$ \\
\hline & Cmax nanosuspensi : 3,6 $\pm 2,2 \mu \mathrm{g} \cdot \mathrm{h} / \mathrm{mL}$ & \\
\hline & AUC suspensi : $8,1 \pm 0,9 \mu \mathrm{g} / \mathrm{mL}$ & \\
\hline & AUC nanosuspensi : $7,3 \pm 0,5 \mu \mathrm{g} / \mathrm{mL}$ & \\
\hline
\end{tabular}




\begin{aligned} \hline P-therpenyl derivate & AUC larutan : 1,094 $\pm 0,076 \mathrm{mg} / \mathrm{L} \mathrm{h} \\ &$ AUC nanosuspensi : 5,183 $\pm 0,247 \mathrm{mg} / \mathrm{L} \mathrm{h} \\ &$ MRT larutan : 0,997 $\pm 0,059 \mathrm{jam} \\ &$ MRT nanosuspensi : 2,832 $\pm 0,218 \mathrm{jam}\end{aligned}$

Keterangan : AUC (area under curve), MRT (mean residence time)

Tabel 5. Keamanan penggunaan intravena dari sediaan nanosuspensi

\begin{tabular}{|c|c|c|}
\hline Nama & Keamanan penggunaan intravena & Pustaka \\
\hline \multirow[t]{2}{*}{ Curcumin } & $\begin{array}{c}\text { Erythrocyte hemolysis rate } 3,31 \pm 0,48 \% \text { untuk larutan, } \\
\text { dan } 1,18 \pm 0,12 \% \text { untuk nanosuspensi }\end{array}$ & $(25)$ \\
\hline & $\begin{array}{c}\text { Sediaan nanosuspensi tidak menyebabkan kerusakan } \\
\text { histopatogi pada vascular irritability test. }\end{array}$ & \\
\hline \multirow[t]{2}{*}{ Sorafenib } & $\begin{array}{l}\text { Erythrocyte hemolysis rate }<5 \% \text { pada konsentrasi } \\
\text { pemberian nanosuspensi } 10-50 \mu \mathrm{g} / \mathrm{mL} \text {. }\end{array}$ & (31) \\
\hline & $\begin{array}{c}\text { Sediaan nanosuspensi tidak menyebabkan kerusakan } \\
\text { histopatogi pada vascular irritability test. }\end{array}$ & \\
\hline Genkwanin & $\begin{array}{l}\text { Tidak menyebabkan terjadinya hemolisis pada pemberiaan } \\
\text { sediaan pada konsenetrasi }<6 \mathrm{mg} / \mathrm{mL}\end{array}$ & $(32)$ \\
\hline $\begin{array}{l}\text { Hydroxy } \\
\text { genkwanin }\end{array}$ & $\begin{array}{l}\text { Tidak terjadi hemolisis pada pemberian nanosuspensi } 1,2 \\
\text { and } 4 \mathrm{mg} / \mathrm{mL} \text {, dan terjadi hemolisis }<8 \% \text { pada konsentrasi } \\
66 \mathrm{mg} / \mathrm{mL} .\end{array}$ & $(33)$ \\
\hline
\end{tabular}

\section{Pembahasan}

Nanosuspensi merupakan sistem dispersi koloidal mengandung partikel obat dengan ukuran $<1 \mu \mathrm{m}$ yang distabilkan oleh surfaktan dan atau polimer (38). Nanosuspensi diketahui mampu meningkatkan kelarutan obat yang sukar larut dalam air. Nanosuspensi dikembangkan untuk berbagai sistem penghantaran obat salah satunya adalah untuk rute intravena (39). Banyak hal yang harus diperhatikan dalam pengembangan obat untuk penghantaran intravena. Kaitan dengan formulasi nanosuspensi, perlu dijamin bahwa bahan penstabil yang digunakan baik itu surfaktan, polimer, ataupun kombinasi keduanya aman untuk digunakan secara parenteral khususnya untuk rute pemberian intravena. Berdasarkan data yang ditampilkan pada tabel 1 diketahui bahwa bahan penstabil yang banyak dikembangkan untuk sediaan nanosuspensi parenteral adalah poloxamer 188, lesitin, TPGS, dan albumin. 
Poloxamer digunakan sebagai bahan penstabil utama pada pengembangan nanosuspensi 2-methoxyestradiol, MTKi-327, PIK-75, dan p-terphenyl derivative yang dikombinasikan dengan bahan penstabil lainnya. Empat senyawa tersebut merupakan agen sitotoksik dengan mekanisme kerja yang berbeda. Poloxamer dengan nama dagang pluronic adalah kopolimer polioksietilen-polioksipropilen yang merupakan nonionic amphiphilic copolymer (40). 2-methoxyestradiol menggunakan poloxamer 188 sebagai penstabil utama, dengan penambahan CMC-Na dan natrium lauril sulfat (22). Poloxamer-188 adalah polimer sintetik yang aman untuk digunakan baik secara oral, parenteral, ataupun topikal karena masuk kategori GRAS (generally regarded as safe) menurut FDA $(6,25)$. Poloxamer-188 berperan sebagai polimer sekaligus surfaktan untuk menstabilkan sistem nanosuspensi dengan prinsip stabilisasi sterik (ruang) (42). Poloxamer 188 diketahui memberikan keuntungan karena selain mampu menjadi penstabil juga dapat membantu mempermudah proses pembasahan zat aktif yang hidrofob (14). Poloxamer-188 dikombinasi dengan CMC-Na sebagai polimer untuk meningkatkan efek stabilisasi sterik juga dengan penambahan natrium lauril sulfat sebagai surfaktan anionik untuk memberikan efek stabilisasi elektrostatik. Natrium lauril sulfat dalam formulasi ini digunakan dalam konsentrasi yang sangat kecil yakni $0,1 \%$ karena diketahui dapat menyebabkan toksisitas akut pada pemberian intravena (43).

MTKi-327, PIK-75, dan p-terphenyl derivative menggunakan kombinasi poloxamer dan lesitin sebagai penstabil. Kombinasi bahan penstabil umum dilakukan untuk meningkatkan efek stabilisasi yang terjadi. Lesitin adalah amino acid-based stabilizer diketahui memberikan efek stabilisasi permukaan (6). Lesitin atau fosfatidilkolin akan membentuk lapisan pelindung pada permukaan nanopartikel dan akan memberikan efek penghalang sterik sehingga akan mencegah terjadinya agregasi dan dapat meningkatkan stabilitasnya (44). Lesitin banyak digunakan sebagai bahan penstabil nanosuspensi karena sifatnya yang biokompatibel dan biodegradabel yang aman untuk digunakan. Lesitin diketahui dapat diberikan secara intravena karena aman untuk digunakan sampai konsentrasi $21 \%$ menurut FDA's Inactive Ingredient Database (IID) for IV route (45).

Pada formulasi nanosuspensi azritomisin, curcumin, bifendat, docetaxel, dan sorafenib juga digunakan lesitin sebagai bahan pestabil. Pada nanosuspensi azritomisin dan docetaxel, lesitin digunakan dalam bentuk tunggal, sedangkan pada senyawa lainnya dibuat dalam bentuk kombinasi. Pada nanosuspensi curcumin lesitin dikombinasikan dengan sodium deoxycholate (SDC) sebagai penstabil. SDC membantu proses stabilisasi lesitin, karena merupakan surfaktan anionik, sehingga bisa memberikan stabilisasi elekstrostatik (25). Sebagai surfaktan anionik, penggunaan SDC pada rute pemberian intravena masih harus dikaji lebih lanjut. Beberapa sumber menyebutkan resiko efek samping yang muncul karena penggunaan SDC secara intravena pada konsentrasi tertentu (25). Pada nanosuspensi bifendat, lesitin dikombinasi dengan PVPK30. PVPK30 adalah polimer yang dapat membantu memberikan stabilisasi sterik dari lesitin (26). PVP (povidone), diketahui aman digunakan dengan tetap memperhatikan batas keamanan pada FDA's Inactive Ingredient Database (IID) for IV route (44). Untuk injeksi sorafenib, lesitin dikombinasi dengan tween 80 sebagai surfaktan nonionik, sehingga membantu proses stabilisasi sterik (31). 
Penstabil lainnya yang banyak digunakan adalah TPGS. TPGS atau $D$-a-tocopheryl polyethylene glycol 1000 succinate adalah polimer amfifilik yang dapat teradsorpsi pada permukaan partikel obat dan secara signifikan mengurangi tegangan permukaan. Selain itu, TPGS dapat mencegah agregasi partikel obat karena efek sterik sehingga menjaga stabilitas sistem (46). TPGS disebutkan aman untuk digunakan secara intravena dengan tetap memperhatikan dosis maksimalnya. TPGS digunakan secara tunggal pada nanosuspensi curcumin, genkwanin, hydroxy genkwanin, dan paclitaxel.

Bahan penstabil selanjutnya adalah bovine serum albumin (BSA). Albumin diketahui sebagai pembawa yang ideal untuk penghantaran obat karena biokompatibel, biodegradabel, non toksik, dan non imunogenik. Disebutkan bahwa albumin masuk ke dalam amino acid-based stabilizer dengan efek stabilisasi permukaan (10). BSA akan berinteraksi dengan partikel membentuk lapisan pelindung sehingga menyebabkan stabilisasi sterik. Selain itu, karena pengaruh titik isoelektrik dari albumin, maka partikel akan bermuatan negatif dan akan menyebabkan stabilisasi elektrostatik (35). Pada nanosuspensi hydroxycamptothecin/HCPT dibuat sediaan nanosuspensi dengan menggunakan fetal calf serum. Fetal calf serum atau kadang fetal bovine serum adalah serum yang diperoleh dari janin sapi dengan metode tertentu. Dijelaskan dalam artikel penggunaan fetal calf serum merujuk pada kandungan protein di dalamnya seperti BSA yang diketahui dapat menstabilkan sistem nanosuspensi. Penggunaan fetal calf serum juga diketahui akan meningkatkan stabilitas plasma sehingga sesuai untuk penggunaan intravena (36).

Berdasarkan data pada tabel 2, diketahui bahwa formulasi nanosuspensi mampu meningkatkan disolusi. Pengujian disolusi yang dilakukan terhadap azritomisin, hydroxycamptothecin, curcumin, bifendate, dan PIK-75 menunjukkan terjadinya peningkatan yang sangat signifikan pada disolusinya. Seperti disebutkan sebelumnya bahwa zat aktif tersebut secara alami memiliki kelarutan yang rendah dalam air, dan hal tersebut menjadi salah satu dasar untuk mengembangkannya menjadi sediaan nanosuspensi. Peningkatan disolusi akibat formulasi nanosuspensi terjadi karena penurunan ukuran partikel, meningkatkan luas permukaan, meningkatkan kontak zat dengan air, sehingga memperbaiki kelarutan/disolusinya. Kondisi tersebut merujuk pada persamaan Noyes-Whitney $(23,44)$. Selain meningkatkan disolusi, formulasi nanosuspensi juga meningkatkan pelepasan zat aktif melalui pengujian in vitro drug release (Tabel 3). Hal ini terjadi pada, nanosuspensi genkwanin, hydroxy genkwanin, dan sorafenib. Peningkatan \% pelepasan zat aktif berkaitan dengan pembahasan sebelumnya, dimana pengecilan ukuran partikel nanosuspensi, dapat menyebabkan peningkatan luas permukaan sehingga mempermudah penembusan zat melalui membran dialisis. (36) Pada pengujian lainnya, dilakukan profil pelepasan zat aktif dari sediaan nanosuspensi dibandingkan dengan sediaan injeksi (marketed product) yakni pada hydroxycamptothecin dan etoposide. Hasilnya menunjukkan bahwa \% pelepasan zat aktif relatif sama antara sediaan nanosuspensi dan marketed produk dalam bentuk injeksi. Akan tetapi, perbedaan terlihat pada profil pelepasannya. Sediaan nanosuspensi terlihat 
memberikan profil pelepasan yang diperlambat ained released). Sistem tersebut dapat menjadi nilai tambah karena dapat memperpnjang waktu sirkulasi zat aktif. Adanya bahan pestabil di sekeliling partikel seperti BA diduga membuat terjadinya pelepasan obat secara bertahap (36).

Pengembangan sediaan nanosuspensi juga berpengaruh signifikan kepada profil farmakokinetika (tabel 4). Pengembangan sediaan nanosuspensi terhadap MTKi-31, hydroxycamptothecin, curcumin, bifendat, pactitaxel, dan p-therpenyl derivate, secara umum meningkatkan nilai AUC, Cmax, dan MRT. Nilai AUC menggambarkan jumlah obat yang sampai ke darah sehingga bisa menggambarkan ketersediaan hayati-nya (48). Nilai Cmax menggambarkan konsentrasi maksimal obat sedangkan MRT adalah rata-rata waktu tinggal obat di tubuh (49). Dari hasil tersebut dapat dikatakan bahwa formulasi nanosuspensi khususnya pada ke- 5 senyawa tersebut, mampu meningkatkan ketersediaan hayati obat dan memperpanjang efek obat di dalam tubuh. Pengembangan nanosuspensi menjadi sesuai untuk penghantaran zat dengan kelarutan yang rendah dalam air dan berpeluang untuk dikembangkan menjadi sediaan dengan sistem pelepasan diperlambat (sustained release), dengan durasi kerja yang lebih panjang sehingga menurunkan frekuensi penggunaan (26). Terjadinya peningkatan nilai AUC dan MRT pada sediaan nanosuspensi diketahui disebabkan oleh terjadinya proses fagositasi partikel nanosuspensi oleh organ-organ reticulate endothelial system (RES), yang kemudian pada waktu tertentu zat akan dilepaskan kembali ke darah, sehingga menyebabkan waktu tinggal di darah menjadi lebih lama dibandingkan bentuk larutan $(43,47)$.

Untuk pengembangan sediaan nanosuspensi secara intravena sangat perlu perlu diperhatikan terkait keamanan penggunaannya. Pengujian keamanan untuk penggunaan intravena umumnya dilakukan dengan erythrocyte hemolysis test dan vascular irritability test (tabel 5). Uji tersebut dilakukan untuk melihat resiko pemberian sediaan intravena terhadap terjadinya hemolisis sel darah dan terjadinya iritasi vaskular (37). Dari sejumlah artikel yang dikaji hanya sebagian kecil yang sudah melakukan pengujian ini yakni pada nanosuspensi curcumin, sorafenib, genkwanin, dan hydroxy genkwanin. Dari ke-4 artikel tersebut, terlihat bahwa pemberian nanosuspensi aman digunakan secara intravena ditandai dengan nilai erythrocyte hemolysis rate $<5 \%$ dan tidak terjadinya kerusakan histopatologi vaskular. Dosis yang digunakan berbeda-beda untuk setiap zat aktif, yang merujuk pada dosis efektif penggunaan intravena (33). Keamanan dari pemberian intravena salah satunya dapat dipengaruhi oleh komponen sediaan baik itu zat aktif ataupun bahan tambahan, dalam hal sediaan nanosuspensi adalah bahan penstabil. Bahan penstabil yang digunakan untuk 4 senyawa tesebut yakni lesitin dan TPGS, dapat dikatakan terbukti aman untuk digunakan secara intravena. (27) 


\section{Kesimpulan}

Sediaan nanosuspensi dapat diaplikasikan untuk penghantaran intravena senyawa aktif dengan kelarutan yang rendah dalam air. Bahan penstabil utama yang digunakan pada pengembangan nanosuspensi inravena aadalah poloxamer/pluronic, lesitin, TPGS, dan bovine serum albumin (BSA) yang bersifat biokompatibel dan non toksik, dengan harus memperhatikan kadar maksimal merujuk pada FDA's Inactive Ingredient Database (IID) for IV route. Pengembangan nanosuspensi secara signifikan mampu meningkatkan disolusi dan pelepasan zat aktif dibandingkan dengan bentuk murni atau suspensinya. Pengembangan nanosuspensi pada beberapa bahan aktif mampu merubah profil farmakokinetika ditandai dengan peningkatan nilai AUC dan MRT dengan profil pelepasan diperlambat (sustained release). Pengembangan nanosuspensi pada beberapa bahan aktif telah terbukti aman digunakan secara intravena berdasarkan uji hemolisis sel darah dan iritasi vascular.

\section{Daftar Pustaka}

1. Wanigasekara J, Witharana C. Applications of nanotechnology in drug delivery and design - an insight. Curr Trends Biotechnol Pharm. 2016;10(1).

2. Safari J, Zarnegar Z. Advanced drug delivery systems: Nanotechnology of health design A review. Vol. 18, Journal of Saudi Chemical Society. 2014.

3. Shinde NC, Keskar NJ, Argade PD. Nanoparticles: Advances in drug delivery systems. Vol. 3, Research Journal of Pharmaceutical, Biological and Chemical Sciences. 2012.

4. Park K. Nanotechnology: What it can do for drug delivery. Vol. 120, Journal of Controlled Release. 2007.

5. Mastiholimath VS, Bhagat Ankita R, Mannur VS, Dandagi PM, Gadad AP, Khanal $P$. Formulation and evaluation of cefixime nanosuspension for the enhancement of oral bioavailability by solvent-antisolvent method and its suitable method development. Indian J Pharm Educ Res. 2020;54(1).

6. Azimullah S, Vikrant, Sudhakar C, Kumar P, Patil A, Md. Usman MR, et al. Nanosuspensions as a promising approach to enhance bioavailability of poorly soluble drugs : An update. J Drug Deliv Ther. 2019;9(2).

7. Wang $Y$, Zheng $Y$, Zhang L, Wang Q, Zhang D. Stability of nanosuspensions in drug delivery. J Control Release. 2013 Dec 28;172(3):1126-41.

8. Bilgili E, Li M, Afolabi A. Is the combination of cellulosic polymers and anionic surfactants a good strategy for ensuring physical stability of BCS Class II drug nanosuspensions? Pharm Dev Technol. 2016;21(4).

9. Sattar A, Chen D, Jiang L, Pan Y, Tao Y, Huang L, et al. Preparation, characterization and pharmacokinetics of cyadox nanosuspension. Sci Rep. $2017 ; 7(1)$.

10. Jacob $S$, Nair $A B$, Shah J. Emerging role of nanosuspensions in drug delivery systems. Vol. 24, Biomaterials Research. 2020. 
11. Haranath C, Hindustan Abdul Ahad Pushpalatha Gutty R, Kalpana K, Sai Priyanka M, Devika P. Nanosuspension as Promising and Potential Drug Delivery: A Review. Int J Pharma Bio Sci. 2021;11(1).

12. Liu T, Müller RH, Möschwitzer JP. Effect of drug physico-chemical properties on the efficiency of top-down process and characterization of nanosuspension. Vol. 12, Expert Opinion on Drug Delivery. 2015.

13. Du J, Li X, Zhao H, Zhou Y, Wang L, Tian S, et al. Nanosuspensions of poorly water-soluble drugs prepared by bottom-up technologies. Vol. 495, International Journal of Pharmaceutics. 2015.

14. Shilpa C, Shrenik K, Ritesh M, Sachin J, Mukesh R. Nanosuspension-A Novel Approaches in Drug Delivery System. Int J Pharma Res Rev. 2013;2(12).

15. Purkayastha H Das, Hossian Ski. Nanosuspension: A Modern Technology Used In Drug Delivery System. Int J Curr Pharm Res. 2019;

16. Jin JF, Zhu LL, Chen M, Xu HM, Wang HF, Feng XQ, et al. The optimal choice of medication administration route regarding intravenous, intramuscular, and subcutaneous injection. Vol. 9, Patient Preference and Adherence. 2015.

17. Pu X, Sun J, Li M, He Z. Formulation of Nanosuspensions as a New Approach for the Delivery of Poorly Soluble Drugs. Curr Nanosci. 2012;5(4).

18. Yuan Q, Wang Y, Song R, Hou X, Yu K, Zheng J, et al. Study on formulation, in vivoexposure, and passive targeting of intravenous itraconazole nanosuspensions. Front Pharmacol. 2019;10(MAR).

19. Priani SE, Setianty TN, Aryani R, Fitrianingsih SP, Syafnir L. Development of Nanocapsules Containing Cytotoxic Agents- A Review. J Farm Galen (Galenika J Pharmacy). 2021;7(2).

20. Hardianti M, Yuniarto A, Hasimun P. Review: Zebrafish (Danio Rerio) Sebagai Model Obesitas dan Diabetes Melitus Tipe 2. J Sains Farm Klin. 2021;8(2).

21. Arora D, Khurana B, Rath G, Nanda S, Goyal AK. Recent Advances in Nanosuspension Technology for Drug Delivery. Curr Pharm Des. 2018;24(21).

22. Shen G, Wang Q, Zhang Q, Sun H, Zhao Y, Zhang Z, et al. Tissue distribution of 2-methoxyestradiol nanosuspension in rats and its antitumor activity in C57BL/6 mice bearing lewis lung carcinoma. Drug Deliv. 2012;19(7).

23. Danhier F, Ucakar B, Vanderhaegen ML, Brewster ME, Arien T, Préat V. Nanosuspension for the delivery of a poorly soluble anti-cancer kinase inhibitor. Eur J Pharm Biopharm. 2014;

24. Hou CD, Wang JX, Le Y, Zou HK, Zhao H. Preparation of azithromycin nanosuspensions by reactive precipitation method. Drug Dev Ind Pharm. 2012;38(7).

25. Gao Y, Li Z, Sun M, Guo C, Yu A, Xi Y, et al. Preparation and characterization of intravenously injectable curcumin nanosuspension. Drug Deliv. 2011;18(2).

26. Liu Y, Zhang D, Duan C, Jia L, Xie P, Zheng D, et al. Studies on pharmacokinetics and tissue distribution of bifendate nanosuspensions for intravenous delivery. $\mathrm{J}$ Microencapsul. 2012;29(2).

27. Wang L, Li M, Zhang N. Folate-targeted docetaxel-lipid-based-nanosuspensions for active-targeted cancer therapy. Int J Nanomedicine. 2012;7. 
28. Talekar M, Kendall J, Denny W, Jamieson S, Garg S. Development and evaluation of PIK75 nanosuspension, a phosphatidylinositol- 3-kinase inhibitor. Eur J Pharm Sci. 2012;47(5).

29. Talekar M, Ganta S, Amiji M, Jamieson S, Kendall J, Denny WA, et al. Development of PIK-75 nanosuspension formulation with enhanced delivery efficiency and cytotoxicity for targeted anti-cancer therapy. Int $\mathrm{J}$ Pharm. 2013;450(1-2).

30. Tian X, Li H, Zhang D, Liu G, Jia L, Zheng D, et al. Nanosuspension for parenteral delivery of a p-terphenyl derivative: Preparation, characteristics and pharmacokinetic studies. Colloids Surfaces B Biointerfaces. 2013;108.

31. Yang S, Zhang B, Gong X, Wang T, Liu Y, Zhang N. In vivo biodistribution, biocompatibility, and efficacy of sorafenib-loaded lipid-based nanosuspensions evaluated experimentally in cancer. Int J Nanomedicine. 2016;11.

32. Li Y, Hong J, Li H, Qi X, Guo Y, Han M, et al. Genkwanin nanosuspensions: A novel and potential antitumor drug in breast carcinoma therapy. Drug Deliv. 2017;24(1).

33. Ao H, Li Y, Li H, Wang Y, Han M, Guo Y, et al. Preparation of hydroxy genkwanin nanosuspensions and their enhanced antitumor efficacy against breast cancer. Drug Deliv. 2020;27(1).

34. Gao L, Liu G, Kang J, Niu M, Wang Z, Wang H, et al. Paclitaxel nanosuspensions coated with P-gp inhibitory surfactants: I. Acute toxicity and pharmacokinetics studies. Colloids Surfaces B Biointerfaces. 2013;111.

35. Wang Z, Li Z, Zhang D, Miao L, Huang G. Development of etoposide-loaded bovine serum albumin nanosuspensions for parenteral delivery. Drug Deliv. 2015;22(1).

36. Han M, Liu X, Guo Y, Wang Y, Wang X. Preparation, characterization, biodistribution and antitumor efficacy of hydroxycamptothecin nanosuspensions. Int J Pharm. 2013;455(1-2).

37. Kim HJ, Yoo SM, Son HS, Ahn CB, Shin YS, Chung JH, et al. Evaluation of the Performance and Safety of a Newly Developed Intravenous Fluid Warmer. Artif Organs. 2015;39(7).

38. Goel S, Sachdeva M, Agarwal V. Nanosuspension Technology: Recent Patents on Drug Delivery and their Characterizations. Recent Pat Drug Deliv Formul. 2019;13(2).

39. Fujimura H, Komasaka T, Tomari T, Kitano Y, Takekawa K. Nanosuspension formulations of poorly water-soluble compounds for intravenous administration in exploratory toxicity studies: in vitro and in vivo evaluation. J Appl Toxicol. 2016;36(10).

40. Guler N, Abro S, Emanuele M, lqbal O, Hoppensteadt D, Fareed J. Functional Protection of Platelets By Tri-Block Polymer (Poloxamer-188) As Studied in Agonist Induced Platelet Aggregation Systems. Blood. 2015;126(23).

41. Giuliano E, Paolino D, Fresta M, Cosco D. Mucosal applications of poloxamer 407-based hydrogels: An overview. Vol. 10, Pharmaceutics. 2018. 
42. Jain D, Athawale R, Bajaj A, Shrikhande S, Goel PN, Gude RP. Studies on stabilization mechanism and stealth effect of poloxamer 188 onto PLGA nanoparticles. Colloids Surfaces B Biointerfaces. 2013;109.

43. Wang Y, Li X, Wang L, Xu Y, Cheng X, Wei P. Formulation and pharmacokinetic evaluation of a paclitaxel nanosuspension for intravenous delivery. Int $\mathrm{J}$ Nanomedicine. 2011;6.

44. Patel D, Zode SS, Bansal AK. Formulation aspects of intravenous nanosuspensions. Vol. 586, International Journal of Pharmaceutics. 2020.

45. Agrawal $\mathrm{Y}$, Patel V. Nanosuspension: An approach to enhance solubility of drugs. J Adv Pharm Technol Res. 2011;

46. Rajamani S, Sengodan T, Thangavelu S, Shanmukhan NK, Radhakrishnan A. Naringenin-loaded TPGS polymeric nanosuspension: In-vitro and in-vivo antiinflammatory activity. Indones J Pharm. 2019;30(3).

47. Bhargav E, Chaithanya Barghav G, Padmanabha Reddy Y, Pavan kumar C, Ramalingam P, Haranath C. A Design of Experiment (DoE) based approach for development and optimization of nanosuspensions of telmisartan, a BCS class II antihypertensive drug. Futur J Pharm Sci. 2020;6(1).

48. Scheff JD, Almon RR, Dubois DC, Jusko WJ, Androulakis IP. Assessment of pharmacologic area under the curve when baselines are variable. Pharm Res. 2011;28(5).

49. Ďuršiová M. Physiologically based structure of mean residence time. Sci World J. 2012;2012.

50. Sajeev Kumar B, Saraswathi R, Venkates Kumar K, Jha SK, Venkates DP, Dhanaraj SA. Development and characterization of lecithin stabilized glibenclamide nanocrystals for enhanced solubility and drug delivery. Drug Deliv. 2014;21(3).

51. Gao Y, Li Z, Sun M, Li H, Guo C, Cui J, et al. Preparation, characterization, pharmacokinetics, and tissue distribution of curcumin nanosuspension with TPGS as stabilizer. Drug Dev Ind Pharm. 2010;36(10). 